\title{
IMPLEMENTASI KURIKULUM 2013 UNTUK MENINGKATKAN KUALITAS PENDIDIKAN DI INDONESIA (KAJIAN PROSES PEMBELAJARAN K-13 DI KOTA TARAKAN DAN KABUPATEN BULUNGAN KALIMANTAN UTARA)
}

\section{Implementation of Kurikulum 2013 to Improve Quality of Education in Indonesiia (Study of Learning Process K-13 in Tarakan and Bulungan, North Kalimantan)}

\author{
Ibrahim $^{\mathrm{a}^{*}}$, Ridwan $^{\mathrm{b}}$, Arifin $^{\mathrm{b}}$ \\ a Program Studi Pendidikan Biologi, Universitas Borneo Tarakan, Tarakan, Kalimantan Utara \\ b Program Studi Pendidikan Bahasa Inggris, Universitas Borneo Tarakan, Kalimantan Utara \\ "Corresponding author: Jl. Amal Lama, Tarakan Timur, Tarakan, Kalimantan Utara, 77123, Indonesia. E-mail: \\ ibrahim_top77@borneo.ac.id
}

\begin{abstract}
Penelitian ini bertujuan untuk mengetahui pemahaman guru di Tarakan dan Bulungan terkait Kurikulum 2013. Penelitian ini menggunakan pendekatan kualitatif, dengan jenis penelitian deskriptif. Terdapat 3 hal yang diukur, yaitu pemahaman terkait proses, materi dan penilaian. Hal yang cukup menarik, terdapat persentase yang besar terkait pemahaman guru dalam proses pembelajaran. Persentase guru SD yang kurang paham sebesar 52,63\%, guru SMP sebesar $26,08 \%$, dan guru SMA sebesar 40,62\%.
\end{abstract}

Abstrak

\section{Kata kunci}

Kurikulum 2013, Pemahaman Guru

\section{Abstract}

The aim of this research is to know the understanding of teachers in Tarakan and Bulungan about Kurikulum 2013. This research used qualitative approach (descriptive analysis). There are 3 main topic that is measured consist of: the understanding of learning process, content, and assessment. The result showed the majority of teachers that did not understand about learning process in Kurikulum 2013. In addition, the percentage primary school teachers that did not understand is $52,63 \%$. The secondary high school teacher that did not understand is $26,08 \%$. The senior high school teachers that did not understand is $40,62 \%$.

Keywords

Kurikulum 2013, Understanding of Teachers 


\section{Pendahuluan}

Kementerian Pendidikan dan Kebudayaan RI melakukan berbagai upaya untuk meningkatkan pembangunan dan kualitas pendidikan di Indonesia, salah satunya adalah mengembangkan kurikulum pendidikan nasional yaitu Kurikulum 2013 yang mulai diimplementasikann secara bertahap pada tahun 2013 di beberapa sekolah sasaran. Tahun ajaran 2014/2015, implementasi Kurikulum 2013 akan diterapkan di seluruh sekolah.

Komponen terpenting implementasi kurikulum adalah pelaksanaan proses pembelajaran yang diselenggarakan di dalam dan/atau luar kelas untuk membatu peserta didik mencapai kompetensi sikap, pengetahuan dan keterampilan. Peraturan Menteri Pendidikan dan Kebudayaan nomor 65 tahun 2013 tentang Standar Proses menyatakan bahwa proses pembelajaran menggunakan metode pembelajaran yang sesuai dengan karakteristik peserta didik dan mata pelajaran. Di antara metode yang dianjurkan dalam Standar Proses tersebut adalah metode saintifik/ilmiah, inkuiri, pembelajaran berbasis masalah dan pembelajaran berbasis projek pada semua mata pelajaran. Pendekatan/metode lainnya yang dapat diimplementasikan antara lain pembelajaran kontekstual dan pembelajaran kooperatif.

Demikian pula dengan penilaian kurikulum 2013, Peraturan Menteri Pendidikan dan Kebudayaan Republik Indonesia Nomor 66 Tahun 2013 tentang Standar Penilaian Pendidikan menyebutkan bahwa hasil penilaian oleh pendidik dan satuan pendidikan dilaporkan dalam bentuk nilai dan deskripsi pencapaian kompetensi kepada orang tua dan pemerintah. Standar Penilaian Pendidikan pun menyebutkan bahwa laporan hasil penilaian oleh pendidik berbentuk: 1) Nilai dan deskripsi pencapaian kompetensi untuk hasil penilaian kompetensi pengetahuan serta keterampilan termasuk penilaian hasil pembelajaran tematik- terpadu; 2) Deskripsi sikap diberikan untuk hasil penilaian kompetensi sikap spiritual dan sikap sosial; 3) Penilaian oleh masing-masing pendidik secara keseluruhan dilaporkan kepada orang tua/wali peserta didik dalam bentuk Laporan Hasil Belajar Peserta Didik.

Walaupun banyak guru di Indonesia telah mengenal metode-metode pembelajaran dan model penilaian tersebut, pengimplementasian kedua hal tersebut di dalam kelas merupakan hal yang belum biasa. Untuk mengimplementasikannya, guru memerlukan pemahaman yang utuh pada setiap tahap pembelajaran.

Untuk memastikan bahwa seluruh proses implementasi Kurikulum 2013 tahun ajaran 2014/2015 ini berjalan sesuai dengan arahan, petunjuk serta tujuan yang diharapkan maka perlu dilakukan kajian ilmiah tentang implementasi kurikulum 2013 di Kalimantan Utara melalui survey dan observasi tentang proses pembelajaran. Hasil kajian ini diharapkan dapat memberikan data kualitatif serta data kuantitatif terkait proses implementasi kurikulum 2013 khususnya di propinsi Kalimantan Utara. Dan selanjutnya akan dijadikan dasar untuk perbaikan dan penyempurnaan dalam implementasi kurikulum 2013 di masa yang akan datang.

\section{Material dan metode}

\section{Metode Penelitian}

Metode penelitian dapat diartikan sebagai strategi mengatur latar (setting) penelitian agar peneliti memperoleh data yang tepat (valid) sesuai dengan karakteristik variabel dan tujuan penelitian (Saukah, 1993). Penelitian deskriptif dirancang untuk memperoleh informasi tentang suatu gejala pada saat penelitian dilakukan. Penelitian ini diarahkan untuk menetapkan sifat suatu situasi pada waktu penyelidikan itu dilakukan. Tujuan penelitian itu adalah untuk melukiskan variabel atau kondisi "apa yang ada" dalam suatu situasi (Furchan, 


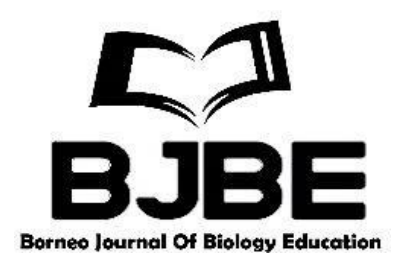

1982). "Penelitian deskriptif digunakan untuk menjelaskan fenomena sebagai-mana adanya" (Slavin, 1992). Lebih jauh Ali (1984) menyatakan bahwa metode penelitian deskriptif untuk memecahkan atau menjawab permasalahan yang sedang dihadapi pada situasi sekarang. Tujuan utama yaitu untuk membuat gambaran tentang sesuatu keadaan secara objektif dalam suatu deskripsi situasi.

Dalam metode deskriptif terdapat jenis-jenis pelaksanaan penelitian antara lain survey, studi kasus, studi perbandingan, studi korelasi, studi prediksi, studi pertumbuhan dan studi kecenderungan (proyeksi). Berdasarkan paparan diatas dan dilihat dari permasalahan serta tujuan penelitian ini maka penelitian ini merupakan penelitian deskriptif berjenis survey.

\section{Sampel Penelitian}

Sampel penelitian meliputi guru SD, SMP, dan SMA/SMK dengan jumlah 139 responden yang. Sampel ditentukan dengan purposive sampling yaitu Kota Tarakan dan Kabupaten Bulungan. Indikator yang menjadi tolok ukur tingkat pemahaman tentang proses dan penilaian dalam pembelajaran yaitu pemahaman guru tentang proses pembelajaran kurikulum 2013 ( langkah-langkah pendekatan saintifik, discovery learning, collaborated learning, projek based learning, dan model pembelajaran apa saja yang dapat membentuk karakter siswa), Pemahaman guru tentang penilaian kurikulum 2013, pemahaman tentang cara pembuatan rencana program pembelajaran.

Untuk memperoleh data yang valid guna membuktikan dalam pemecahan masalah yang diajukan dalam penelitian ini, adalah:

1. Angket Respon

Angket yang digunakan dalam penelitian ini, berupa daftar pertanyaan tertulis yang disusun untuk mendapatkan informasi tentang tingkat pemahaman guru yang berkaitan dengan proses pembelajaran dan penilaian hasil belajar siswa pada kurikulum 2013.

2. Observasi

Pengamatan dan pencatatan secara sistematis terhadap gejala yang tampak pada objek penelitian dengan cara mengadakan pengamatan secara langsung di dalam kelas. Dari observasi yang dilakukan peneliti, maka peneliti dapat memperoleh informasi secara langsung tentang keadaan proses dan model penilaian guru didalam kelas. Lembar observasi merupakan alat yang sangat penting dalam penelitian kualitatif, dengan maksud untuk melengkapi data yang belum terekam pada angket selama pelajaran berlangsung.

\section{Teknis Analisis Data}

Untuk mengetahui tingkat pemahaman guru tentang proses dan model penilaian dalam kegiatan pembelajaran, perlu dilakukan analisis data. Pada penelitian ini,digunakan analisis deskripsi kualitatif, yaitu suatu metode yang bersifat menggambarkan kenyataan atau fakta sesuai dengan data yang diperoleh. Data angket dianalisis dengan persentase.

$$
\% \text { Pemahaman }=\frac{\text { Skor yang diperoleh }}{\text { Skor Maksimal }} X 100 \% \text { (Sumber }: \text { Uzer dalam Rasid, 2010) }
$$




\section{Hasil dan Diskusi}

Deskripsi Hasil survey terhadap kuisioner yang diedarkan kepada guru SD, SMP, dan SMA/SMK. Jumlah responden secara keseluruhan adalah sebanyak 139 responden, yang terdiri dari guru SD 38 responden, SMP 69 responden, dan SMA/SMK 32 responden.

1. Analisis Tingkat Pemahaman Guru tentang proses pembelajaran kurikulum 2013 (langkahlangkah pendekatan saintifik, discovery learning, project based learning, dan model pembelajaran apa saja yang dapat membentuk karakter siswa)

Tabel 1. Tingkat Pemahaman Guru tentang proses pembelajaran kurikulum 2013

\begin{tabular}{lccc}
\hline \multicolumn{1}{c}{ Kategori } & SD $(\%)$ & SMP $(\%)$ & SMA/SMK $(\%)$ \\
\hline Tidak Paham & 0 & 7,25 & 6,25 \\
Kurang Paham & 52,63 & 26,08 & 40,62 \\
Paham & 44,73 & 66,67 & 53,12 \\
Sangat Paham & 2,63 & 0 & 0 \\
\hline
\end{tabular}

Berdasarkan tabel 1 dapat dijelaskan bahwa tingkat pemahaman guru SD tentang proses pembelajaran kurikulum 2013 yaitu Guru yang kurang paham sebesar 52,63\% dan guru yang paham 44,73\%. Guru SMP tidak paham 7,25\%, kurang paham 26,08\%, dan paham 66,67\%. Sedangkan untuk jenjang SMA/SMK tidak paham 6,25\%, kurang paham 40,62\%, dan paham $53,12 \%$.

Tabel 2. Pemahaman tentang Langkah-langkah Pendekatan Saintifik

\begin{tabular}{lccc}
\hline \multicolumn{1}{c}{ Langkah-langkah } & Jenjang & \\
& SD $(\%)$ & SMP $(\%)$ & SMA/SMK $(\%)$ \\
\hline Mengamati & 94,74 & 95,20 & 96,87 \\
Menanya & 86,84 & 88,40 & 84,37 \\
Mencoba & 73,68 & 84,06 & 68,75 \\
Menalar & 84,21 & 81,16 & 75 \\
Mengkomunikasikan & 73,68 & 85,51 & 93,75 \\
\hline
\end{tabular}

Berdasarkan Tabel 2 dapat dijelaskan bahwa tingkat pemahaman guru SD, SMP, dan SMA/SMK tentang langkah-langkah pembelajaran kurikulum 2013 termasuk kategori paham. Meskipun Pada langkah mencoba terdapat 75,50\% guru pada semua jenjang yang paham. Maka masih terdapat 24,50 belum paham pada langkah mencoba dalam proses pembelajaran.

Tabel 3. Pemahaman tentang Discovery Learning dan Project Based Learning

\begin{tabular}{ccccccc}
\hline & & \multicolumn{2}{c}{ Jenjang } & \multicolumn{2}{c}{ SMP } & \multicolumn{2}{c}{ SMA/SMK } \\
Pendekatan & $\begin{array}{c}\text { SD } \\
\text { Paham }\end{array}$ & $\begin{array}{c}\text { Tidak Paham } \\
(\%)\end{array}$ & $\begin{array}{c}\text { Paham } \\
(\%)\end{array}$ & $\begin{array}{c}\text { Tidak Paham } \\
(\%)\end{array}$ & $\begin{array}{c}\text { Paham } \\
(\%)\end{array}$ & $\begin{array}{c}\text { Tidak } \\
\text { Paham }(\%)\end{array}$ \\
\hline $\begin{array}{c}\text { Discovery } \\
\text { Learning } \\
\text { Project } \\
\text { Based }\end{array}$ & 95 & 5 & 100 & 0 & 94 & 6 \\
Learning & 82 & 18 & 90 & 10 & 91 & 9 \\
\hline
\end{tabular}




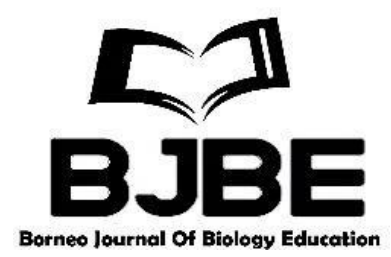

Berdasarkan Tabel 3 diatas dapat dipaparkan bahwa guru pada semua jenjang telah memahami tentang pendekatan Discovery Learning yaitu dengan tingkat pemahaman secara teoritis 82 sampai dengan $100 \%$. Namun berdasarkan hasil observasi proses pembelajaran di kelas kebanyakan guru masih sulit menerapkan kedua pendekatan tersebut. Hal ini disebabkan karena 1) mindset dari seorang guru belum berubah 2) guru masih terpaku pada buku pegangan guru dan 3) pemahaman tentang pengintegrasian antara pendekatan saintifik dengan pendekatan Discovery learning, Problem based learning dan project based learning masih rendah.

Tabel 4. Model pembelajaran apa saja yang dapat membentuk karakter siswa

\begin{tabular}{|c|c|c|c|}
\hline \multirow{2}{*}{ Model Pembelajaran } & \multicolumn{3}{|c|}{ Jenjang } \\
\hline & $\mathrm{SD}(\%)$ & $\operatorname{SMP}(\%)$ & SMA/SMK $(\%)$ \\
\hline $\begin{array}{l}\text { Membuat siswa terbuka untuk menerima pesan/sikap } \\
\text { yang baik }\end{array}$ & 92,11 & 89,86 & 87,50 \\
\hline Mengajak anak untuk menjelaskan/meniru & 52,63 & 46,38 & 37,50 \\
\hline $\begin{array}{l}\text { Memberi pemahaman pada anak untuk } \\
\text { menghargai atau memilih sikap-sikap tersebut }\end{array}$ & 71,05 & 73,91 & 87,50 \\
\hline $\begin{array}{l}\text { Melakukan penghargaan melaui pengorganisasi } \\
\text { sikap }\end{array}$ & 63,16 & 60,87 & 59,38 \\
\hline Menjadikan amalan & 26,32 & 41,94 & 28,13 \\
\hline
\end{tabular}

Berdasarkan tabel diatas dapat dijelaskan bahwa model pembelajaran yang dapat membentuk karakter siswa adalah model yang membuat siswa terbuka untuk menerima pesan/sikap yang baik dan model pembelajaran yang memberi pemahaman pada anak untuk menghargai atau memilih sikap-sikap yang baik ditambah dengan model pembelajaran melakukan penghargaan melalui pengorganisasi sikap.

2. Analisis Tingkat Pemahaman Guru tentang Materi pembelajaran kurikulum 2013

Tabel 5. Pemahaman Guru tentang Materi pembelajaran kurikulum 2013

\begin{tabular}{lccc}
\hline \multicolumn{1}{c}{ Kategori } & Jenjang & \\
& SD $(\%)$ & SMP $(\%)$ & SMA/SMK $(\%)$ \\
\hline Tidak Paham & 2,63 & 0 & 9 \\
Kurang Paham & 57,89 & 20 & 31 \\
Paham & 36,84 & 80 & 60 \\
Sangat Paham & 2,63 & 0 & 0 \\
\hline
\end{tabular}

Berdasarkan Tabel 5 dapat dijelaskan bahwa jenjang guru SD masih kurang paham tentang materi pembelajaran kurikulum 2013 yaitu dengan tingkat persentase 60,52\%, SMP $20 \%$, dan SMA/SMK 40\%. Perbedaan ini disebabkan oleh buku pegangan guru dan siswa belum merata pada jenjang SD dan SMA/SMK, proses pendampingan kurikulum 2013 belum berjalan pada jenjang SD dan SMA/SMK, dan faktor akses informasi tentang materi kurikulum 2013 yang masih kurang. 


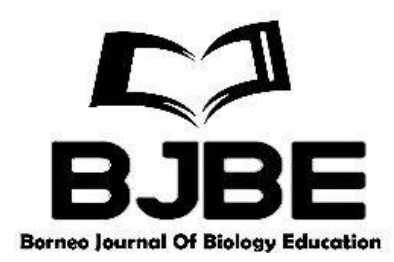

3. Analisis Tingkat Pemahaman Guru tentang Penilaian Kurikulum 2013

Tabel 6. Pemahaman Guru tentang Penilaian Kurikulum 2013

\begin{tabular}{lccc}
\multicolumn{1}{c}{ Kategori } & Jenjang & \\
& SD $(\%)$ & SMP $(\%)$ & SMA/SMK $(\%)$ \\
\hline Tidak Paham & 5 & 6 & 16 \\
Kurang Paham & 63 & 33 & 34 \\
Paham & 29 & 61 & 50 \\
Sangat Paham & 3 & 0 & 0 \\
\hline
\end{tabular}

Berdasarkan Tabel 6 dapat dijelaskan bahwa tingkat pemahaman guru tentang penilaian pada kurikulum 2013 masih rendah. Berdasarkan jenjang pendidikan guru SD tingkat pemahamanya tentang penilaian baru mencapai 32\%, SMP 61\%, dan SMA/SMK 50\%. Hal ini disebabkan jumlah jam untuk materi penilaian dalam kegiatan pelatihan kurikulum 2013 masih kurang dan bahkan tidak tersampaikan.

Tabel 7. Macam-macam Penilaian Guru Kurikulum 2013

\begin{tabular}{lccc}
\hline \multicolumn{1}{r}{ Penilaian } & SD $(\%)$ & Jenjang & \\
& 71 & 97 & SMA/SMK $(\%)$ \\
\hline Penilaian Otentik & 82 & 83 & 91 \\
Ulangan Harian & 63 & 81 & 65 \\
UTS/UAS & 34 & 65 & 53 \\
Penilaian Project & & & \\
\hline
\end{tabular}

Berdasarkan Tabel 7 dapat dijelaskan bahwa pengetahuan tentang macam-macam penilaian pada penilaian project masih rendah dibanding dengan penilaian otentik, UH, dan UTS/UAS. Berdasarkan jenjang pendidikan guru SD tingkat pengtahuan tentang penilaian project baru mencapai 34\%, SMP 65\%, dan SMA/SMK 53\%. Hal ini disebabkan jumlah jam untuk materi penilaian dalam kegiatan pelatihan kurikulum 2013 masih kurang dan belum adanya buku pegangan guru SD dan SMA/SMK.

Tabel 8. Cara melakukan Penilaian Otentik

\begin{tabular}{lccc}
\hline \multicolumn{1}{c}{ Kategori } & \multicolumn{3}{c}{ Jenjang } \\
& SD $(\%)$ & SMP $(\%)$ & SMA/SMK (\%) \\
\hline Paham & 63 & 70 & 75 \\
Tidak Paham & 37 & 30 & 25 \\
\hline
\end{tabular}

Berdasarkan Tabel 8 dapat dijelaskan bahwa pengetahuan tentang cara melakukan penilaian otentik dapat dikategorikan paham. Meskipun pada jenjang guru SD baru mencapai $63 \%$, SMP 70\%, dan SMA/SMK 75\%. Hasil observasi di kelas kegiatan penilaian otentik pada aspek sikap tidak dilakukan sehingga tidak sejalan dengan pengetahuan guru tentang cara melakukan penilaian otentik.

Tabel 9. Cara melakukan Penilaian Project

\begin{tabular}{lccc}
\hline \multicolumn{1}{c}{ Kategori } & \multicolumn{3}{c}{ Jenjang } \\
& SD $(\%)$ & SMP $(\%)$ & SMA/SMK $(\%)$ \\
\hline Paham & 92 & 90 & 87 \\
Tidak Paham & 8 & 10 & 13 \\
\hline
\end{tabular}




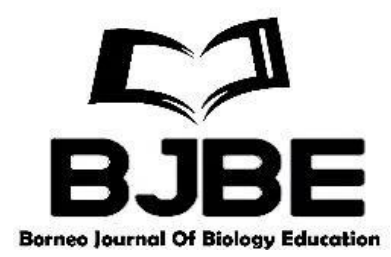

Berdasarkan Tabel 9 dapat dijelaskan bahwa pengetahuan tentang cara melakukan penilaian Project dapat dikategorikan sangat paham. Namun hasil observasi di kelas kegiatan penilaian project tidak pernah dilakukan sehingga tidak sejalan dengan pengetahuan guru tentang cara melakukan penilaian project.

Tabel 10. Bagaimana guru menggunakan hasil penilaian diri yang dilakukan siswa

\begin{tabular}{lccc}
\hline \multicolumn{1}{c}{ Kategori } & \multicolumn{3}{c}{ Jenjang } \\
& SD $(\%)$ & SMP $(\%)$ & SMA/SMK (\%) \\
\hline Tidak Paham & 32 & 49 & 44 \\
Paham & 68 & 51 & 56 \\
\hline
\end{tabular}

Berdasarkan Tabel 10 dapat dijelaskan bahwa pengetahuan tentang cara menggunakan hasil penilaian diri yang dilakukan siswa dapat dikategorikan kurang paham. Pada jenjang guru SD baru mencapai 68\%, SMP 51\%, dan SMA/SMK 56\%. Hal ini disebabkan para guru baru mengenal penilaian diri yang dilakukan oleh siswa sendiri. Hasil observasi di sekolah hasil penilaian diri yang dilakukan siswa oleh guru belum dilaksanakan.

Tabel 11. Pemahaman Guru Cara Membuat RPP

\begin{tabular}{lccc}
\hline Kategori & \multicolumn{3}{c}{ Jenjang } \\
& SD $(\%)$ & SMP $(\%)$ & SMA/SMK $(\%)$ \\
\hline Tidak Paham & 5 & 4 & 9 \\
Kurang Paham & 55 & 32 & 35 \\
Paham & 40 & 62 & 56 \\
Sangat Paham & 0 & 2 & 0 \\
\hline
\end{tabular}

Berdasarkan Tabel 11 dapat dijelaskan bahwa pemahaman guru tentang cara membuat RPP secara umum dapat dikategorikan kurang paham. Tingkat pemahaman pada jenjang guru SD baru mencapai 40\%, SMP 64\%, dan SMA/SMK 56\%. Kurangnya pemahaman guru dalam membuat RPP disebabkan para guru mengenal RPP model baru, ketersediaan buku, sistem penilaian dan kurangnya praktek membuat RPP pada saat pelatihan.

Tabel 12. Cara menyesuaikan konteks untuk bahan menyusun RPP

\begin{tabular}{lccc}
\hline Kategori & \multicolumn{3}{c}{ Jenjang } \\
& SD $(\%)$ & SMP $(\%)$ & SMA/SMK (\%) \\
\hline Paham & 84 & 96 & 87 \\
Tidak Paham & 16 & 4 & 13 \\
\hline
\end{tabular}

Berdasarkan Tabel 12 dapat dijelaskan bahwa pemahaman guru tentang cara menyesuaikan untuk bahan menyusun RPP secara umum dapat dikategorikan sangat paham. Tingkat pemahaman pada jenjang guru SD sudah mencapai 84\%, SMP 96\%, dan SMA/SMK $87 \%$. 


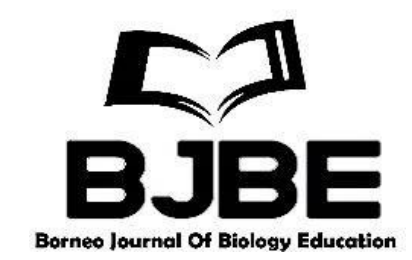

Tabel 13. Cara memilih sumber belajar yang akan digunakan

\begin{tabular}{lccc}
\hline Kategori & \multicolumn{3}{c}{ Jenjang } \\
& SD $(\%)$ & SMP $(\%)$ & SMA/SMK $(\%)$ \\
\hline Paham & 84 & 93 & 84 \\
Tidak Paham & 16 & 7 & 16 \\
\hline
\end{tabular}

Berdasarkan Tabel 12 dapat dijelaskan bahwa pemahaman guru tentang cara memilih sumber belajar yang akan digunakan secara umum dapat dikategorikan sangat paham. Tingkat pemahaman pada jenjang guru SD sudah mencapai 84\%, SMP 93\%, dan SMA/SMK 84\%.

\section{Kesimpulan}

Penelitian ini berusaha untuk mengetahui perspektif dan pemahaman guru terkait kurikulum 2013. Terdapat 3 hal yang dinilai, yaitu: a) analisis tingkat pemahaman guru tentang proses pembelajaran kurikulum 2013 (langkah-langkah pendekatan saintifik); b) analisis tingkat pemahaman guru tentang materi pembelajaran kurikulum 2013; dan c)Analisis Tingkat Pemahaman Guru tentang Penilaian Kurikulum 2013. Terdapat hal menarik yang ditemukan yaitu terkait pemahaman terkait proses pembelajaran pada tingkat pendidikan SD, SMP dan SMA, dimana presentasenya masih cukup tinggi. Persentase guru SD yang kurang paham sebesar 52,63\%, guru SMP sebesar 26,08\%, dan guru SMA kurang paham 40,62\%.

\section{Daftar Pustaka}

Ali, Mohammad. (1984). Metodelogi Penelitian. Bandung: Angkasa

Furchan, A. (1982).Pengantar Penelitian dalam Pendidikan. Usaha Nasional :Surabaya

Menteri Pendidikan dan Kebudayaan., (2013) Peraturan Menteri Pendidikan dan Kebudayaan Republik Indonesia Nomor 66 Tahun 2013 tentang Standar Penilaian Pendidikan.

Saukah, A. (1993) Pedoman Penulisan Karya Ilmiah. Universitas Negeri Malang. Malang

Slavin, R.E. (1992). When and why does cooperative learning increase achievement? Theoretical and empirical perspectives. In R. Hertz-Lazarowitz \& N. Miller (Eds.), Interaction in cooperative groups: The theoretical anatomy of group learning (pp. 145173). New York: Cambridge University Press. 